MaPan : Jurnal Matematika dan Pembelajaran

p-ISSN: 2354-6883 ; e-ISSN: 2581-172X

Volume 6, No 2, December 2018 (207-220)

DOI: https://doi.org/10.24252/mapan.2018v6n2a7

\title{
ANALISIS KESALAHAN MAHASISWA DALAM MENYELESAIKAN SOAL KALKULUS PEUBAH BANYAK
}

\author{
Dian Septi Nur Afifah'),Muhammad Ilman Nafi'an²), Ika Mariana Putri ${ }^{3)}$ \\ 1,2,3 STKIP PGRI Tulungagung \\ 1,2,3 Jalan Mayor Sujadi Timur No. 7 Tulungagung \\ Email: dian.septi@stkippgritulungagung.ac.id ${ }^{1)}$ \\ $\underline{\text { ilman@stkippgritulungagung.ac.id }}^{2)}$, $\underline{\text { ikamarianaputri@gmail.com }}^{3}$
}

Submitted: 02-07-2018, Revised: 22-09-2018, Accepted: 26-09-2018

\begin{abstract}
Abstrak:
Tujuan penelitian ini untuk menganalisis kesalahan dan faktor penyebab mahasiswa dalam menyelesaikan soal pada mata kuliah kalkulus peubah banyak. Jenis penelitian ini menggunakan penelitian deskriptif kualitatif, karena mendeskripsikan dan menggali informasi dengan kata-kata. Subjek penelitian adalah mahasiswa program studi pendidikan matematika semester lima STKIP PGRI Tulungagung. Subjek dipilih berdasarkan banyaknya kesalahan yang dilakukan dan kemampuan komunikasi lancar. Instrumen utama adalah peneliti sendiri dan instrumen pendukung adalah soal kalkulus peubah banyak. Teknik pengumpulan data menggunakan tes dan wawancara. Untuk menguji keabsahan data digunakan triangulasi teknik. Analisis data dilakukan dengan reduksi data, penyajian data dan penarikan kesimpulan. Hasil penelitian menunjukkan bahwa jenis kesalahan yang dilakukan meliputi jenis kesalahan konsep (aturan rantai dan penggunaan harga mutlak, turunan trigonometri ,turunan parsial, konsep integral dan eksponen), kesalahan operasi (perkalian antara koefisien dan variabel dari sebuah fungsi dan operasi bilangan bulat) dan jenis kesalahan prinsip (penulisan rumus aturan rantai).
\end{abstract}

Kata Kunci: Analisis Kesalahan Mahasiswa, Kalkulus Peubah Banyak

\section{THE ANALYSIS OF STUDENTS' ERRORS IN ANSWERING MULTIVARIABLE CALCULUS TESTS}

\begin{abstract}
:
The research aims to analyze the students' errors and the factors causing the errors in answering the multivariable calculus tests. The research used qualitative descriptive research because it described and deeply explored the information narratively. The research subject was the 5th semester students of mathematics education department in STKIP PGRI Tulungagung. The subjects were selected based on the number of errors made by the students and their ability to communicate smoothly. The main research instrument was the researchers themselves and the secondary instrument was the multivariable calculus test. Data collection technique used test and interviews. To test the data validity, the researchers used triangulation technique. Data analysis was conducted through data reduction, data presentation and conclusion. The research findings indicated that the error types made by the students consisted of conceptual errors (chain rule and use of absolute price,
\end{abstract}


trigonometric derivatives, and partial derivatives, integral and exponent), operational errors (multiplication of coefficients and variables of a function and integer operation) and principle errors (writing the formula of chain rule).

Keywords: The Analysis of Students' Error, Multivariable Calculus

How to Cite: Afifah, D. S. N., Nafi'an, M. I., \& Putri, I. M. (2018). Analisis Kesalahan Mahasiswa dalam Menyelesaikan Soal Kalkulus Peubah Banyak. MaPan : Jurnal Matematika dan Pembelajaran, 6 (2), 207-220.

alkulus Peubah Banyak atau biasanya disingkat KPB merupakan
salah satu mata kuliah yang harus ditempuh mahasiswa prodi
pendidikan matematika. KPB merupakan kalkulus lanjutan yang sebelumnya mahasiswa harus menempuh kalkulus I dan kalkulus II. Jika Kalkulus 1 \& kalkulus 2 umumnya membahas single variable dalam ruang satu dimensi atau dua dimensi, dalam Kalkulus Peubah banyak (KPB) membahas lebih dari satu peubah bebas (independent variable) dalam Ruang lebih dari 1 dimensi. Dalam perkuliahan membahas dalam ruang dua dan/atau tiga dimensi dan dapat diperluas dan dikembangkan pada $n$ dimensi $\mathbb{R}$.

Topik utama yang dibahas dalam Kalkulus adalah diferensial (Diferensial Calculus) dan Integral (Integration Calculus). Adapun deskripsi dari mata kuliah $\mathrm{KPB}$ adalah memberikan pengetahuan dan pendalaman dalam kalkulus fungsi peubah banyak termasuk analisis vektor, cara perhitungan dan analisis dari hasil perhitungan, yang bertujuan menganalisis dan menghitung turunan dan integral dari persoalan kalkulus lebih dari 1 variabel dan memahami aplikasinya. KPB di prodi pendidikan matematika STKIP PGRI Tulungagung diberikan di semester lima. Berdasarkan pengalaman peneliti ketika mengajar KPB di kelas, mahasiswa masih banyak yang belum bisa menggunakan teknik menghitung baik diferensial maupun integral dalam satu peubah.

Selain itu juga berdasarkan analisis hasil Ujian Tengah Semester (UTS) dari kelas 5A dari 30 mahasiswa hanya 10 mahasiswa yang nilainya di $\geq 65$, untuk kelas 5B dari 43 mahasiswa terdapat 12 mahasiswa yang nilainya di $\geq$ 65 dan untuk kelas 5C dari 38 mahasiswa terdapat 4 mahasiswa yang nilainya $\geq 65$. Dari analisis jawaban mahasiswa menunjukkan bahwa terdapat banyak kesalahan mahasiswa dalam teknik menghitung diferensial maupun integral jika melibatkan konsep trigonometri dan eksponesial. 
Setelah dilakukan wawancara kesalahan tersebut diakibatkan mahasiswa tidak memahami konsep yang digunakan.

Menurut Gagne dalam belajar matematika terdapat dua objek yaitu objek langsung dan objek tak langsung. Objek langsung terdiri dari fakta, konsep, skill, dan prinsip (Erman, 2003). Fakta meliputi istilah atau nama, notasi atau lambang/simbol, dan lain-lainnya. Sedangkan konsep merupakan ide abstrak sehingga memungkinkan untuk mengelompokkan suatu objek. Skill berkaitan dengan kemampuan mahasiswa dalam memberikan jawaban, misalnya berupa gabungan konsep dan beberapa fakta. Oleh karena itu, setelah mahasiswa belajar, diharapkan mahasiswa memperoleh pemahaman akan keempat hal tersebut yang saling berkaitan sehingga tidak mengalami kesulitan dalam mengerjakan soal.

Kesulitan yang dialami peserta didik akan memungkinkan terjadi kesalahan sewaktu menjawab soal tes (Fuadi, Johar, \& Munzir, 2016). Sebagaimana kesalahan yang dilakukan mahasiswa dalam menjawab persoalan aljabar adalah bukti adanya kesulitan yang dialami oleh mahasiswa pada materi tersebut. Hubungan antara kesalahan dan kesulitan dapat diperhatikan pada kalimat, "Jika seorang mengalami kesulitan maka ia akan membuat kesalahan" (Limardani, Trapsilasiwi, \& Fatahillah, 2015). Hal tersebut menegaskan bahwa kesulitan menjadi salah satu penyebab terjadinya suatu kesalahan.

Romadiastri (2012) menyatakan bahwa mahasiswa yang melakukan jenis kesalahan pada pemahaman konsep logika sebesar 7,5\%, jenis kesalahan keterampilan 22,1\% dan kesalahan dalam memecahkan masalah sebesar 17,3\%. Hal tersebut dikarenakan oleh beberapa faktor yaitu mahasiswa kurang mengusai konsep pada materi prasyarat, materi abstrak sehingga mahasiswa merasa bosan dan kurang berlatih dalam mengerjakan soal-soal logika. Dalam hal ini jenis kesalahan dibedakan menjadi tiga yaitu pemahaman konsep, keterampilan dan pemecahan masalah.

Widodo (2013) mengidentifikasi kesalahan mahasiswa dalam memecahkan masalah dibedakan menjadi tiga tahap. Tahap pertama kesalahan kebiasaan sebesar 4,41\%, kesalahan interpretasi bahasa 0,69\% dan kesalahan fakta 4, 14\%. Kesalahan tahap dua yaitu kesalahan konsep 8, 28\%, dan kesalahan prinsip 6,9\%. Dan kesalahan tahap ketiga yaitu kesalahan prinsip 4, 14\% dan kesalahan prosedur 14, 48\%. Dalam hal ini jenis kesalahan yang dominan adalah jenis kesalahan konsep dan prosedur.

Kesalahan yang dilakukan mahasiswa perlu diberikan sebuah solusi penyelesaiannya. Untuk mengetahui solusi penyelesaiannya maka 
diperlukan analisis jenis kesalahan apa saja yang dilakukan oleh mahasiswa dalam menyelesaikan soal matematika maupun faktor-faktor penyebabnya. Dengan adanya informasi jenis kesalahan yang dilakukan oleh mahasiswa, dosen dapat menyusun strategi pembelajaran dengan meminimalisir mahasiswa melakukan kesalahan agar tujuan pembelajaran tercapai dan meningkatkan efektifitas pembelajaran matematika (Ardiawan, 2015).

Muchlis (2017) menyatakan bahwa kesalahan merupakan penyimpangan terhadap hal yang benar dan sifatnya sistematis, konsisten maupun insidental pada bagian tertentu. Kesalahan yang bersifat sistematis dan konsisten dipengaruhi oleh kemampuan mahasiswa yang bersifat insidental bukan merupakan akibat rendahnya tingkat penguasaan materi pelajaran. Mutia (2017) menjelaskan bahwa kesalahan adalah penyimpangan terhadap suatu yang benar. Kesalahan dalam menyelesaikan soal-soal matematika dapat dimanfaatkan untuk menganalisis kesulitan mahasiswa dalam belajar matematika. Jadi yang dimaksud kesalahan dalam penelitian ini adalah bentuk penyimpangan terhadap hal yang benar, prosedur yang ditetapkan sebelumnya, atau penyimpangan dari suatu yang diharapkan.

Atim (2008) membedakan kesalahan dalam menyelesaikan soal matematika menjadi dua yaitu kesalahan konsep, yaitu kesalahan yang dibuat oleh siswa karena salah menafsirkan konsep-konsep, operasi-operasi atau salah dalam penerapannya dan kesalahan bukan konsep, yaitu kesalahan yang dibuat siswa karena salah dalam perhitungan. Sedangkan Muchlis (2017) mengidentifikasi jenis kesalahan yang dilakukan siswa pada setiap aspek penguasaan bahan ajar matematika kesalahan konsep yaitu kesalahan yang berkaitan dalam penggunaan konsep-konsep yang digunakan dalam materi, kesalahan operasi yaitu kesalahan yang berkaitan dengan hubungan antara dua atau lebih objek matematika, dan kesalahan prinsip yaitu kesalahan dalam melakukan perhitungan.

Jenis kesalahan yang digunakan dalam penelitian ini adalah kesalahan konsep, kesalahan prinsip, dan kesalahan operasi. Kesalahan konsep, yaitu kesalahan yang di buat mahasiswa dalam menggunakan konsep-konsep yang terkait dengan materi, seperti salah dalam memahami makna soal dan salah tentang konsep diferensial dan integral. Kesalahan prinsip yaitu kesalahan yang dibuat mahasiswa dalam menggunakan prinsip-prinsip yang terkait dengan materi, seperti salah dalam menggunakan rumus-rumus diferensial dan integral dan salah dalam menentukan jawab akhir. Kesalahan operasi yaitu kesalahan yang dilakukan mahasiswa dalam melakukan operasi seperti mahasiswa tidak dapat menggunakan aturan operasi atau 
perhitungan dengan benar dalam teknik menghitung baik diferensial maupun integral.

Rahayu, Muhsetyo, dan Rahardjo (2016) menjelaskan bahwa penyebab kesulitan belajar mahasiswa secara umum dapat dibedakan yaitu kesulitan yang disebabkan oleh faktor kognitif dan non kognitif. Faktor kognitif mencakup kemampuan intelektual dan cara memahami materi matematika. Sedangkan faktor non kognitif antara lain latar belakang keluarga, kesehatan, keadaan ekonomi, dan sosial. Untuk mengetahui faktor penyebab yang disebabkan faktor non kognitif diperlukan waktu yang lebih lama dan indikator yang lebih kompleks. Oleh karena itu, dalam penelitian ini menggunakan faktor penyebab kesalahan yang berasal dari dalam diri mahasiswa yaitu menyangkut faktor kognitif mahasiswa, yakni kemampuan intelektual mahasiswa dalam memahami mata kuliah KPB.

Faktor kognitif mahasiswa yang menyebabkan kesalahan konsep, kesalahan prinsip, dan kesalahan operasi seperti dijelaskan oleh Atim (2008) meliputi kurangnya latihan soal, tidak memahami konsep diferensial dan integral, menghafal prinsip diferensial dan integral namun tidak memahami, prinsip tersebut tidak digunakan dalam menyelesaikan soal, cenderung tidak cermat dan mempersingkat dalam menentukan jawaban akhirnya. Operasi tersebut tidak digunakan dalam menyelesaikan soal, tidak cermat dalam melakukan perhitungan dan tidak mempunyai keterampilan pemahaman terhadap simbol operasi seperti " +","-", "x", ":", $\sqrt{ }$, dan kuadrat. Dalam penelitian ini, faktor-faktor penyebab kesalahan yang disebabkan oleh faktor kognitif digali sedetail yang didasarkan pada pedoman wawancara berdasarkan kesalahan yang dilakukan mahasiswa dalam menyelesaikan soal KPB.

Berdasarkan uraian di atas, maka penulis melakukan penelitian yang bertujuan untuk mendeskripsikan jenis kesalahan dan faktor-faktor yang menyebabkan mahasiswa STKIP PGRI Tulungagung melakukan kesalahan dalam menyelesaikan soal kalkulus peubah banyak. Karena dengan mengetahui jenis kesalahan dan faktor yang penyebabnya, dosen dapat menentukan strategi pembelajaran yang tepat agar mahasiswa tidak melakukan kesalahan dalam menyelesaikan soal KPB. 


\section{METODE PENELITIAN}

Penelitian ini merupakan penelitian deskriptif kualitatif untuk mengungkap, menganalisis, dan memberikan gambaran tentang jenis kesalahan dan faktor-faktor yang menyebabkan yang subjek penelitian melakukan kesalahan. Penelitian dilakukan di kelas $5 \mathrm{C}$ prodi pendidikan matematika STKIP PGRI Tulungagung. Tahap pertama dalam penelitian ini melibatkan semua mahasiswa kelas $C$ semester 5. Dari kelas tersebut kemudian akan dipilih 2 orang secara acak dengan mempertimbangkan kelancaran komunikasi secara lisan.

Teknik pengumpulan data yang digunakan dalam penelitian ini adalah tes tulis dan wawancara. Tes tertulis digunakan untuk mengetahui jenis kesalahan yang dilakukan oleh mahasiswa dalam menyelesaikan soal KPB. Wawancara digunakan untuk mengetahui faktor penyebab mahasiswa melakukan kesalahan dilakukan setelah menganalisis jawaban mahasiswa pada saat tes. Instrumen utama yaitu peneliti sendiri, sedangkan instrumen pendukung adalah soal tes dan pedoman wawancara. Soal tes yang digunakan dalam penelitian ini adalah tes diagnostik yang berbentuk soal uraian. Soal tes yang diujikan adalah soal yang terkait dengan diferensial dan integral lebih dahulu dilakukan validasi, kemudian direvisi sesuai dengan saran-saran yang diberikan oleh para validator. Pedoman wawancara dibuat oleh penulis dengan tujuan untuk mengetahui faktor-faktor penyebab terjadinya kesalahan yang dilakukan mahasiswa dengan melihat pada hasil tes mahasiswa.

Dalam penelitian ini teknik analisis data dilakukan melalui 3 tahap, yaitu: reduksi data, penyajian data dan penarikan kesimpulan. Untuk menguji keabsahan data digunakan triangulasi teknik dengan membandingkan kesalahan dalam menyelesaikan soal tes yang diperoleh dari jawaban subjek penelitian dengan hasil wawancara subjek penelitian.

\section{HASIL PENELITIAN DAN PEMBAHASAN}

Berikut adalah soal tes tulis,

1. Dengan menggunakan aturan Rantai, tentukan diferensial total dari persamaan $z=\sin x \cos y ; x=\pi t \quad, y=\sqrt{t}$

2. Hitunglah Integral Lipat di bawah ini!

$$
\int_{1}^{2} \int_{0}^{2 x} \frac{4 y}{x^{3}+2} d y d x
$$


Berdasarkan hasil jawaban tes tulis (Ujian Akhir Semester Gasal) dipilih dua mahasiswa sebagai subjek penelitian dalam penelitian ini. Subjek yang pertama sebagai S1, dan subjek yang kedua sebagai S2. Berikut adalah deskripsi jenis kesalahan dalam menyelesaikan soal KPB.

\section{Deskripsi Hasil Tes Tulis S1 dalam Menyelesaikan Soal KPB.}

Berikut adalah hasil tes tulis S1 Untuk soal nomor 1,

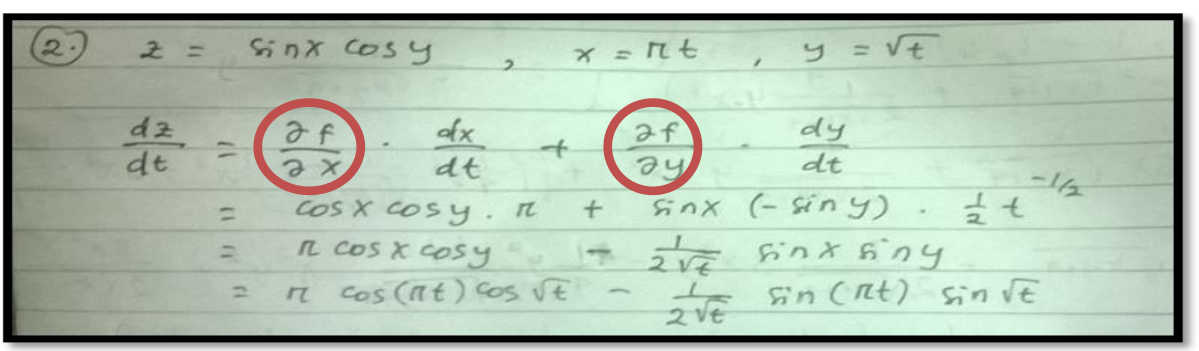

Gambar 1. Hasil Tes Tulis S1 untuk Soal No. 1

Berdasarkan hasil jawaban S1 di atas, tampak bahwa jawaban S1 benar, akan tetapi kurang teliti dalam menuliskan rumusnya. Kesalahan tersebut termasuk pada jenis kesalahan konsep dalam aturan rantai, yang seharusnya $\frac{\partial z}{\partial x}$ dan $\frac{\partial z}{\partial y}$ karena fungsinya dalam $z$ bukan $f$. Kesalahan tersebut disebabkan tidak menguasai konsep aturan rantai dengan benar.

Berikut adalah hasil tes tulis S1 Untuk soal nomor 2,

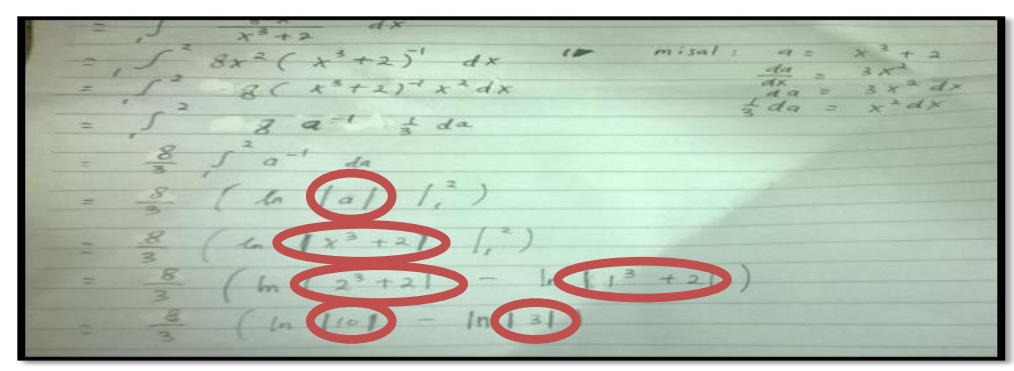

Gambar 2. Hasil Tes Tulis S1 untuk Soal No. 2

Berdasarkan hasil jawaban S1 di atas, tampak bahwa jawaban S1 benar , akan tetapi dalam penulisan simbol masih salah. Kesalahan di atas adalah termasuk jenis kesalahan konsep yaitu dalam penulisan simbol harga mutlak, seharusnya tidak menggunakan tanda harga mutlak. Kesalahan tersebut disebabkan karena S1 tidak memahami konsep harga mutlak dan tanda kurung kurawal dengan benar. Berdasarkan hasil jawaban S1 baik 
nomor satu maupun nomor 2 jenis kesalahan yang dilakukan S1 adalah jenis kesalahan konsep yaitu penulisan simbol harga mutlak.

\section{Deskripsi Hasil Tes Tulis S2 dalam Menyelesaikan Soal KPB.}

Berikut adalah hasil tes tulis S2 Untuk soal nomor 1,

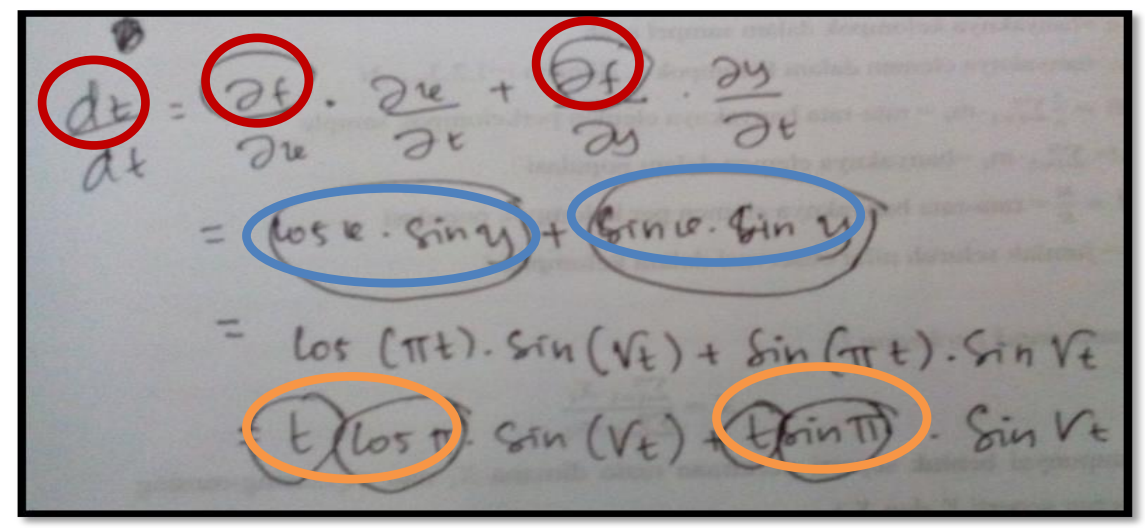

Gambar 3. Hasil Tes Tulis S2 untuk Soal No. 1

Berdasarkan jawaban S2 di atas nomor satu menunjukkan jawabannya salah. Jenis kesalahan yang tampak yaitu jenis kesalahan konsep dan prinsip serta jenis kesalahan operasi. Jenis kesalahan prinsip yaitu salah dalam menggunakan lambang dalam rumus aturan rantai, $\frac{d t}{d t}$ seharusnya $\frac{d z}{d t^{\prime}} \partial f$ harusnya $\partial z$ karena fungsi nya dalam $z$. Faktor yang menyebabkan salah karena tidak memahami konsep dan rumus aturan rantai.

Jenis kesalahan konsep adalah kesalahan konsep yang tidak paham akan konsep turunan trigonometri dan turunan parsial. cos $x$ siny seharusnya $\cos x \cos y$. Dan $\sin x \sin y$ seharusnya $\sin x(-\sin y)$.

Jenis kesalahan operasi tampak pada cuplikan jawaban tes tulis di bawah ini.

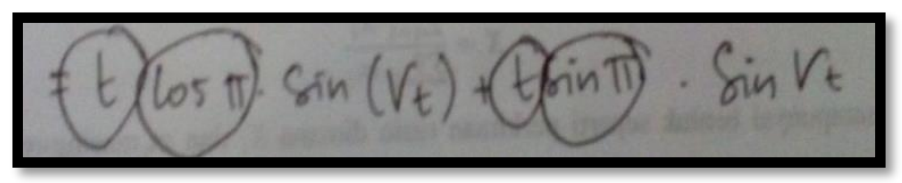

Gambar 4. Kesalahan Operasi pada Cuplikan Jawaban Tes Tulis

Jenis kesalahan yang tampak di atas adalah jenis kesalahan operasi yang menunjukkan bahwa tidak paham perkalian antara koefisien dan variabel dari sebuah fungsi. 
Berikut adalah hasil tes tulis S2 untuk soal nomor 2,

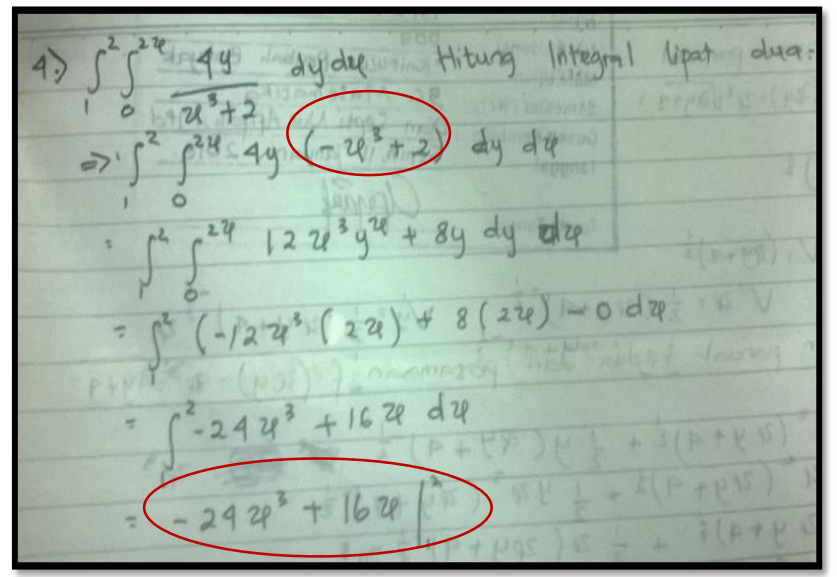

Gambar 5. Hasil Tes Tulis S2 untuk Soal No. 2

Berdasarkan jawaban tes tulis S2 di atas menunjukkan jenis kesalahan konsep, prinsip dan operasi. Jenis kesalahan konsep yaitu mengubah fungsi $\frac{4 y}{x^{3}+2}$ ke dalam fungsi pangkat negatif seharusnya $\left(-x^{3}+2\right)^{-1}$ sehingga S2 dapat dikatakan tidak paham pada konsep eksponensial. Selain itu juga tampak pada cuplikan di bawah ini,

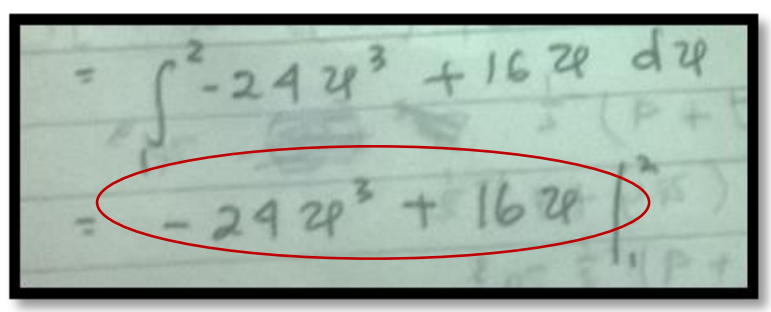

Gambar 6. Kesalahan Konsep

Kesalahan di atas tampak jenis kesalahan konsep tentang integral. S2 juga melakukan kesalahan jenis kesalahan operasi yang dilakukan S2 seperti pada cuplikan di bawah ini,

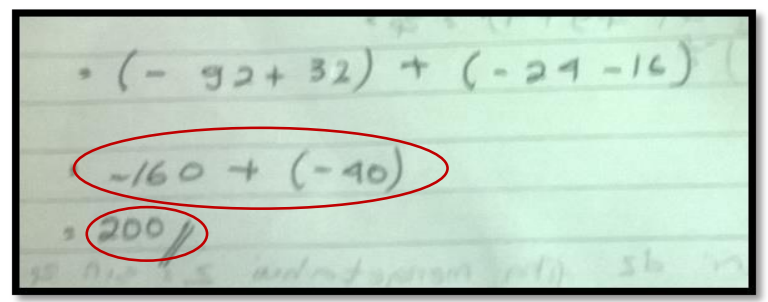

Gambar 7. Kesalahan Operasi yang Dilakukan S2 
Berdasarkan cuplikan di atas, tampak bahwa kesalahan secara algoritma atau perhitungannya. Sehingga termasuk jenis kesalahan operasi. Faktor yang menyebabkan kesalahan adalah tidak teliti dalam melakukan operasi penjumlahan bilangan bulat. Jenis kesalahan yang dilakukan oleh S2 baik dari soal nomor 1 maupun nomor 2 yaitu jenis kesalahan konsep, prinsip dan operasi.

Untuk memperoleh data yang valid, maka dalam penelitian ini digunakan triangulasi teknik, yaitu membandingkan antara hasil tes tulis dan wawancara, Seperti pada tabel 1 di bawah ini,

Tabel 1. Hasil Triangulasi Teknik

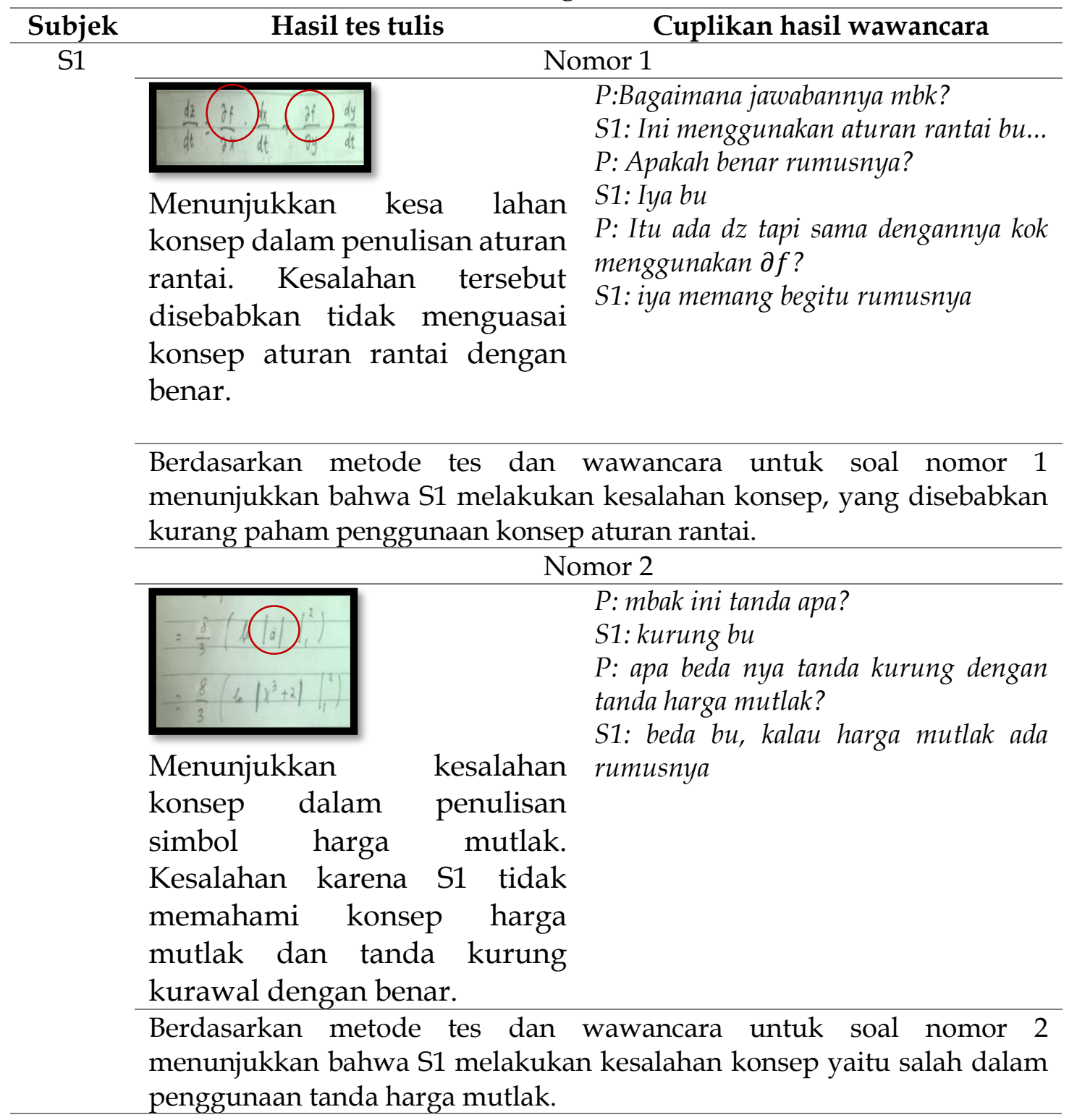




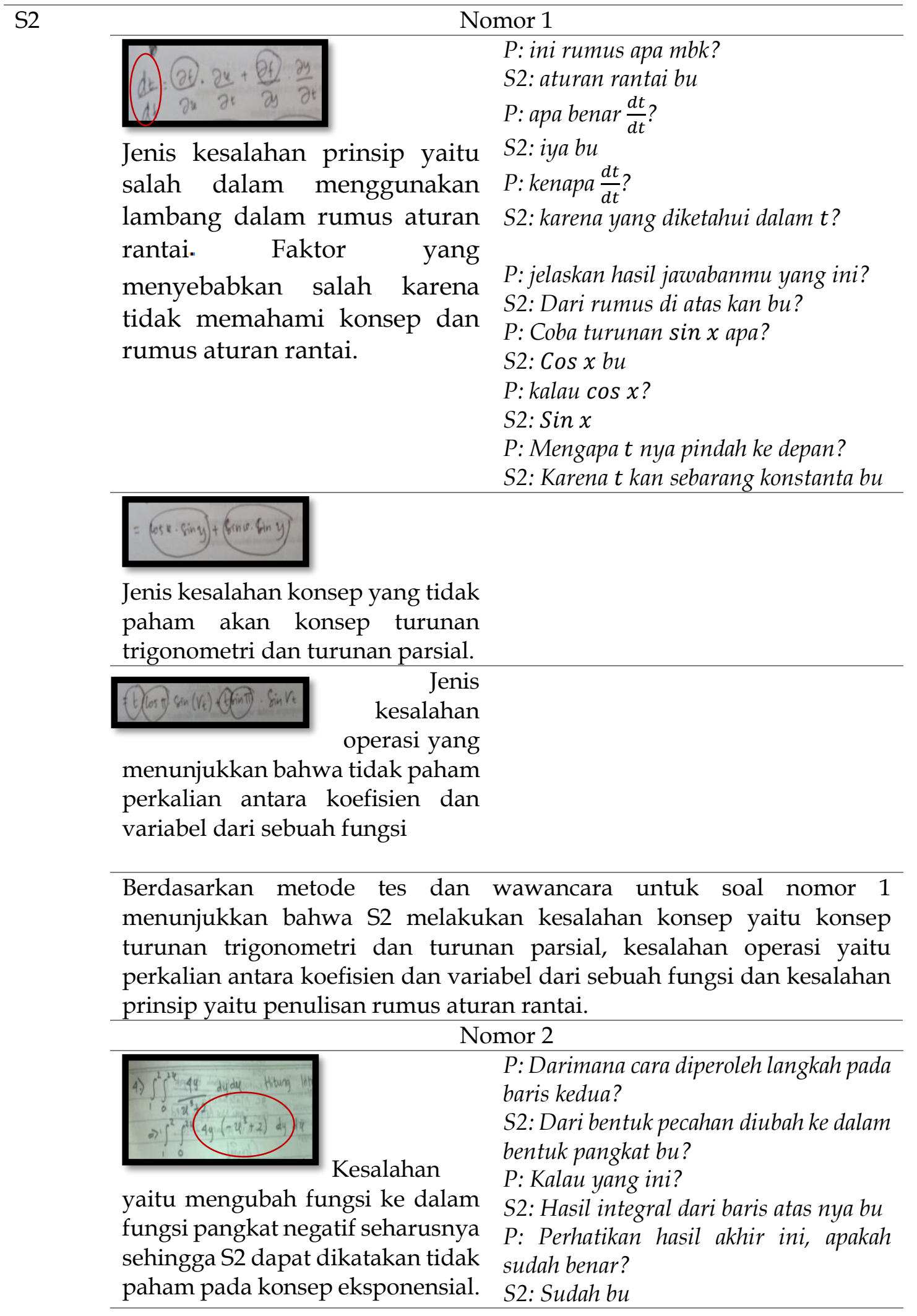




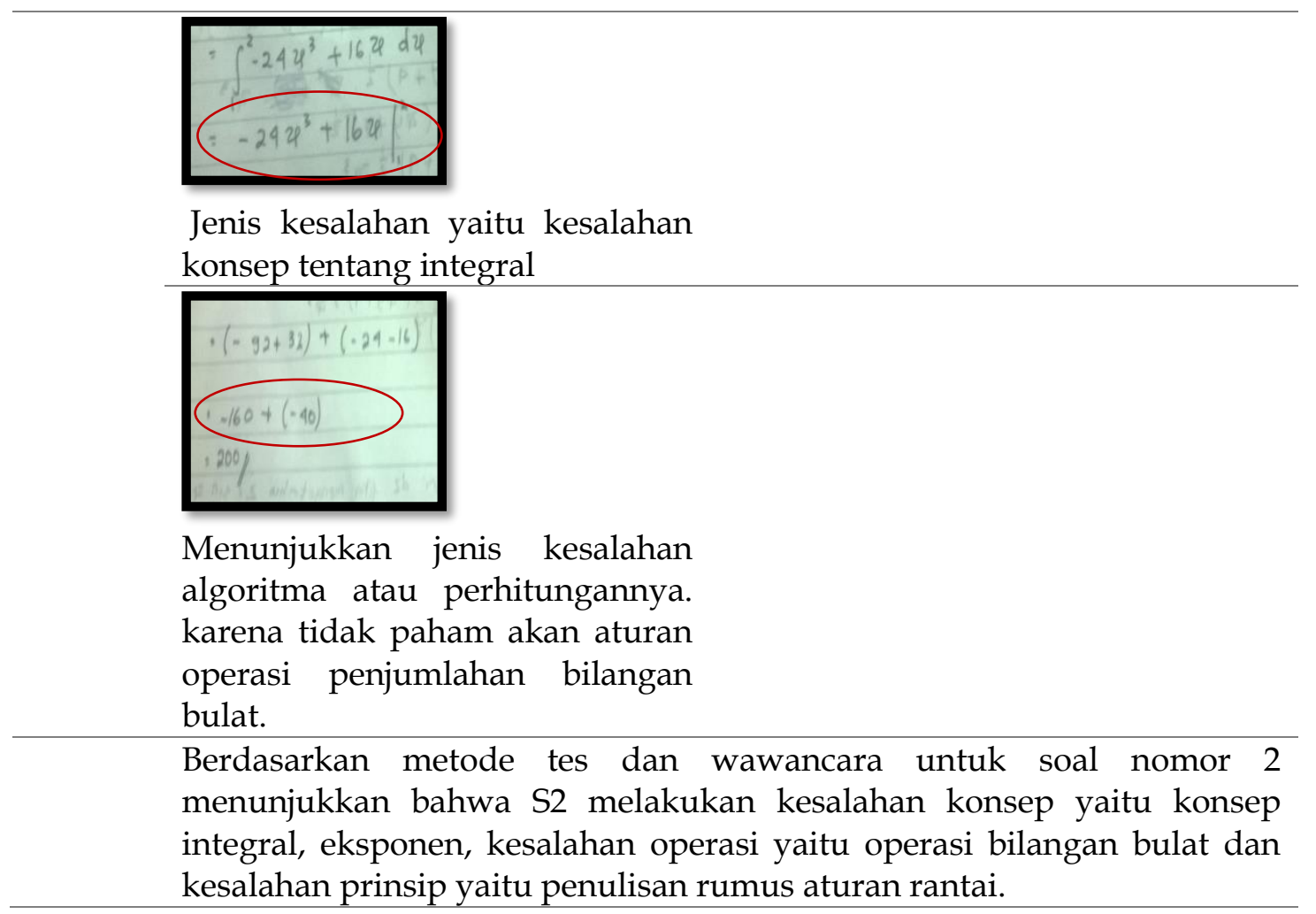

Keterangan:

$P$ adalah Peneliti

S1 adalah Subjek Pertama

S2 adalah Subjek Kedua

Berdasarkan data yang diperoleh maka jenis kesalahan yang dilakukan S1 dalam menyelesaikan soal KPB adalah jenis kesalahan konsep yaitu kesalahan konsep dalam aturan rantai dan penggunaan harga mutlak. Hal tersebut disebabkan karena kurang pahamnya penggunaan rumus aturan rantai dan harga mutlak yang merupakan bagian dari materi prasyarat yaitu kalkulus 1. Sedangkan jenis kesalahan yang dilakukan S2 dalam menyelesaikan soal KPB meliputi jenis kesalahan, yaitu kesalahan konsep, operasi, dan prinsip. Kesalahan konsep yaitu konsep turunan trigonometri ,turunan parsial, konsep integral dan eksponen, kesalahan operasi yaitu perkalian antara koefisien dan variabel dari sebuah fungsi dan operasi bilangan bulat, kesalahan prinsip yaitu penulisan rumus aturan rantai. Faktor yang menyebabkan S2 melakukan kesalahan adalah kurangnya penguasaan konsep trigonometri, eksponen, turunan dan integral, serta kurang teliti dalam melakukan perhitungan. 


\section{SIMPULAN}

Berdasarkan hasil pembahasan, maka dapat disimpulkan bahwa jenis kesalahan yang dilakukan mahasiswa dalam menyelesaikan soal KPB meliputi jenis kesalahan konsep (aturan rantai dan penggunaan harga mutlak, turunan trigonometri, turunan parsial, konsep integral dan eksponen), kesalahan operasi (perkalian antara koefisien dan variabel dari sebuah fungsi dan operasi bilangan bulat) dan jenis kesalahan prinsip (penulisan rumus aturan rantai). Dan faktor-faktor yang menyebabkan mahasiswa melakukan kesalahan yaitu kurang pahamnya akan konsep dan prosedur tentang aturan rantai, harga mutlak, turunan trigonometri, turunan parsial, integral dan eksponen, serta kurang teliti dalam perhitungan.

\section{DAFTAR PUSTAKA}

Ardiawan, Y. (2015). Analisis kesalahan mahasiswa dalam menyelesaikan soal induksi matematika di IKIP PGRI Pontianak. Jurnal Pendidikan Informatika Dan Sains, 4(1), 147-163. Retrieved from http://journal.ikippgriptk.ac.id/index.php/saintek/article/view/13 $/ 11$

Atim, M. (2008). Analisis kesalahan siswa dalam menyelesaikan soal terapan sistem persamaan linear dua variabel di kelas X MAN Gresik I. PPs Unesa.

Erman, S. (2003). Strategi pembelajaran matematika kontemporer. Bandung: JICA Universitas Pendidikan Indonesia.

Fuadi, R., Johar, R., \& Munzir, S. (2016). Peningkatkan kemampuan pemahaman dan penalaran matematis melalui pendekatan kontekstual. Jurnal Didaktika Matematika, 3(1), 47-54. Retrieved from http://www.jurnal.unsyiah.ac.id/DM/article/view/4305/3729

Limardani, G., Trapsilasiwi, D., \& Fatahillah, A. (2015). Analisis kesulitan siswa dalam menyelesaikan soal operasi aljabar berdasarkan teori pemahaman skemp pada siswa kelas VIII D SMP Negeri 4 Jember. Artikel Ilmiah Mahasiswa, 1(1), 1-7.

Muchlis, E. E. (2017). Analisis kesalahan mahasiswa pada materi integral lipat di prodi pendidikan matematika FKIP Universitas Bengkulu (pp. 265-272). Retrieved from http://seminar.uny.ac.id/semnasmatematika/sites/seminar.uny.ac.i d.semnasmatematika/files/full/M-40.pdf 
Mutia. (2017). Analisis kesalahan mahasiswa dalam menyelesaikan soal negasi pernyataan majemuk pada logika matematika. NUMERICAL (Jurnal Matematika dan Pendidikan Matematika), 1(1), 79-92. Retrieved from

https:/ /journal.iaimnumetrolampung.ac.id/index.php/numerical/a rticle/view/121/92

Rahayu, A., Muhsetyo, G., \& Rahardjo, S. (2016). Analisis kesalahan pemahaman siswa dalam menyelesaikan soal cerita materi sistem persamaan linear dua variabel pada siswa SMP Ar-Rohmah. In Pengembangan 4C's dalam Pembelajaran Matematika: Sebuah Tantangan Pengembangan Kurikulum Matematika (pp. 79-84). Retrieved from https:/ / sriyantimustafa.files.wordpress.com/2018/03/berpikirintuitif.pdf

Romadiastri, Y. (2012). Analisis kesalahan mahasiswa matematika dalam menyelesaikan soal-soal logika. Phenomenon, 2(1), 75-93. Retrieved from

http://journal.walisongo.ac.id/index.php/Phenomenon/article/vie $\mathrm{w} / 419 / 383$

Widodo, S. A. (2013). Analisis kesalahan dalam pemecahan masalah divergensi tipe membuktikan pada mahasiswa matematika. Jurnal Pendidikan Dan Pengajaran, 46(2), 106-113. Retrieved from https://www.researchgate.net/publication/311645939_analisis_kesa lahan_dalam_pemecahan_masalah_divergensi_tipe_membuktikan_p ada_mahasiswa_matematika 